\title{
First report of injuries associated with triclopyr herbicide drift in grapevines
}

\section{Primeiro relato de danos associados à deriva do herbicida triclopir em videiras}

\author{
Sergio Ruffo Roberto ${ }^{1 *}$; Werner Genta2; Giliardi Dalazen3; \\ Nathalia Rodrigues Leles ${ }^{4}$
}

\section{Highlights}

Injuries associated with triclopyr drift in grapes are described for the first time.

The associated injuries in shoots, bunches, and berries are documented.

The implications of triclopyr drift in regard to grapevine development are discussed.

\begin{abstract}
In the southern region of Brazil, close proximity of vineyards to soybean areas is common, and glyphosate is used frequently to allow for the control of weeds. However, the continuous use of this chemical has accelerated the process of selection for resistant species such as horseweed (Conyza spp.), thus leading to the search for alternative herbicides such as triclopyr to control this weed. To the best of our knowledge, this is the first report detailing injuries associated with triclopyr drift in grapevines in Brazil, in the Northern region of Parana state, that can result in crop losses that were previously uncharacterized. In this report, the primary symptoms associated with the drift of triclopyr in grapevines are described. Additionally, the major implications of this process regarding vine development along the next crop seasons are explored, and the primary measures to prevent these injuries are discussed.
\end{abstract}

Key words: Viticulture. Table grapes. Auxinic herbicides. Application technology. Vitis vinifera L.

\section{Resumo}

Na região sul do Brasil é comum a proximidade de parreirais às lavouras de soja, sendo que no controle de plantas daninhas é frequentemente utilizado o herbicida glifosato. Porém, o seu uso acelerou o processo de seleção de espécies resistentes, como a buva (Conyza spp.), levando à procura por herbicidas alternativos, como o triclopir para o controle dessa planta daninha. Nesse trabalho é feito o primeiro relato de danos

1 Associate Prof., PhD, Fellow of CNPq, Department of Agronomy, Center for Agricultural Sciences, CCA, Universidade Estadual de Londrina, UEL, Londrina, PR, Brazil. E-mail: sroberto@uel.br

2 Agronomist, M.e, Associação Norte Paranaense em Estudos de Fruticultura, ANPEF, Marialva, PR, Brazil. E-mail: wgenta2@gmail.com

3 Adjunct Prof., PhD, UEL, Londrina, PR, Brazil. E-mail: giliardidalazen@gmail.com

${ }^{4}$ M.e Student in Agronomy, Fellow of CAPES, UEL, Londrina, PR, Brazil. E-mail: nathalia.leles@uel.br

* Author for correspondence

Received: Mar. 03, 2021 - Approved: Sept. 30, 2021 
associados à deriva da aplicação de triclopir em áreas de produção de uvas no Brasil na região Noroeste do Estado do Paraná, causando prejuízos à cultura até então desconhecidos. Nessa comunicação, os principais sintomas associados à deriva desse herbicida em videiras são descritos, bem como discutidas as suas principais implicações no desenvolvimento das videiras nos próximos ciclos produtivos, e as medidas para que os danos sejam evitados.

Palavras-chave: Viticultura. Uvas de mesa. Herbicidas auxínicos. Tecnologia de aplicação. Vitis vinifera L.

The grape industry is one of the most important agricultural activities world-wide. Grapevine cultivation differs according to the existing edaphoclimatic conditions and due to the ultimate use of the grapes that can include their use as fresh or processed fruits (Kishino, Roberto, \& Genta, 2019b).

In the State of Parana in Brazil, grapevine cultivation covers an area of approximately 3,600 ha, particularly in the North and Northwest regions where the production of table grapes (Vitis vinifera L.) predominates and primarily includes the 'Italia' grape and its colored somatic mutations (also known as the 'Italia' group), such as 'Rubi', 'Benitaka' and 'Brasil' (Instituto Brasileiro de Geografia e Estatística [IBGE], 2019; Kishino, Marur, \& Roberto, 2019a).

One of the primary characteristics of table grape production in Paraná state is the double cropping system that allows for two harvest seasons per year (Genta et al., 2010). The first harvest season is known as the regular or summer harvest season and begins after winter pruning during which 6-8 buds are retained per cane, and this harvest occurs in the summer from November to January. The second harvest season is known as the autumn or off-season harvest and begins after summer pruning is performed following the harvest of the summer season during which 12-14 buds are retained per cane. This harvest occurs in autumn from April to June during a period in which the supply of table grapes is low or nonexistent in other producing regions of Brazil (Ahmed et al., 2019; Kishino et al., 2019b).

These table grapes are sensitive to the major herbicides that are commonly used to control weeds. However, broadacre farm roadsides and lawns in close proximity to vineyards are regularly treated with different herbicides or combinations thereof. Herbicide spray droplets, particularly those of the phenoxyacetic acid group (e.g., 2,4-D), can drift off-target by several kilometers (Felsot et al., 2011).

In general, vines may not grow well in areas subject to the drift of auxinic herbicides due to their high susceptibility to these chemicals. In regions where the use of the herbicide 2,4-D is widespread, the yield is significantly impaired by the drift of this herbicide when it is applied in nearby areas. Injury intensity varies depending on the stage of development of the vines and the amount of herbicide drift. This amount varies depending on the distance between the cultivated area and the location where the chemical was applied. Additionally, the topography, the concentration of the product used in the spray solution, climatic conditions, the set of technologies used at the time of application, and the volatility of the product can all result in continued contamination of nearby areas even after application (Kishino et al., 2019b). In 
some counties, specific laws restrict the use of herbicides to prevent harm to growers who cultivate sensitive plant species.

The proximity of vineyards to grain crops such as soybeans, corn, and wheat is quite common in the Southern region of Brazil. For the control of weeds in these crops, growers preferentially use the herbicide glyphosate (primarily after the introduction of soybean and corn cultivars resistant to this herbicide) that was developed using the Roundup Ready (RR) technology. However, the continuous use of glyphosate to the detriment of the use of herbicides possessing other mechanisms of action has accelerated the process of selection and the dispersion of resistant weeds such as horseweed (Conyza spp.) and sourgrass (Digitaria insularis) (Heap, 2020). This has led to the search for alternative herbicides to control the horseweed, and these herbicides include chlorimuron-ethyl, saflufenacil, and 2,4-D as a first application that is followed by the application of paraquat (Tahmasebi et al., 2018). However, the use of paraquat has been recently banned in Brazil, leading companies to offer alternatives to growers that can include the use of triclopyr, fluroxipyr, and dicamba.

Auxin-type herbicides (also known as auxinic herbicides) are classified into four chemical groups that include benzoic acids (dicamba), phenicarboxylic acids (2,4D), carboxylic acids (triclopyr, picloran, and fluroxypyr), and quinoline carboxylic acids (quincloraque) (Nascimento \& Yamashita, 2009). Initially, the application of auxins reduced the $\mathrm{pH}$ of the plant cell wall (apoplastic $\mathrm{pH}$ ) in response to the increased activity of the ATPase proton pump in the cell membrane. This change in $\mathrm{pH}$ induces cell elongation by increasing the activity of cellulase enzymes and loosening the cell wall (Cobb \& Reade, 2010; Shaner, 2014). Another response to the increased auxin concentrations in plant tissues is the greater production of ethylene, a plant growth regulator, ultimately leading to tissue senescence. Additionally, the effect of ethylene in combination with cell elongation and loosening of the cell wall results in the characteristic symptoms observed in plants treated with synthetic auxins such as epinasty (Hansen \& Grossmann, 2000).

The occurrence of injuries caused by 2,4-D in vineyards in Southern Brazil has been frequently reported, and these injuries have led to a significant decrease in the yield and quality of grape production. The characteristic symptoms caused in the grapevine include a morphological alteration of the leaves with an aspect known as "frog-leg" due to the elongation and whiteness of the veins. The resulting injuries include the shriveling of the leaves and a reduction of their size, a reduction in the growth of the shoots, harm to the subsequent harvest seasons, and abortion of the berries when this damage occurs in the initial stage of vine growth (Oliveira et al., 2007).

Recently, injuries associated with triclopyr drift have been observed in several areas of table grape production in Parana state, and these injuries have caused partial or total losses to grapevines that were previously unknown. Additionally, controlled trials examining triclopyr to characterize the levels of damage to vines have not been performed to date, and the primary injuries associated with this herbicide in grapevines also remain unknown. In this report, the main symptoms and injuries associated with triclopyr drift in vines and grape bunches under field conditions are described, and we aim to 
facilitate their recognition at different stages of vine development and to discuss the major implications that will impact the subsequent growing seasons for these grapevines.

On September 7, 2020 in the municipality of Marialva, located in the Northwest of Parana state in Brazil (a traditional table grape and soybean growing area), intense wilt was observed at the tip of the vine shoots in several neighboring vineyards located in close proximity to the coordinates $23^{\circ} 31^{\prime} 2.8^{\prime \prime}$ S; 51⒋ ${ }^{\prime} 38^{\prime \prime} \mathrm{W}$; $540 \mathrm{~m}$ a.s.l., and these characteristics were observed regardless of their development stage (Figure 1). The leaves located in the apical portion of these shoots also exhibited symptoms of shriveling, where their edges were facing upward (Figure 2). These vines were pruned in late winter for harvest in early summer between November and December of the same year.

On the day before the injuries were reported in these vineyards, the herbicide triclopyr-butotyl (butoxyethyl 3,5,6-trichloro- 2-pyridyloxyacetate) was applied to control horseweed (Conyza spp.) in a commercial soybean cultivation area located in close proximity to the coordinates $23^{\circ} 30^{\prime} 57^{\prime \prime} \mathrm{S}$; 51049'34" W at elevation $527 \mathrm{~m}$ a.s.l. The herbicide was applied at approximately 7 a.m. on a sunny day (approximately $18^{\circ} \mathrm{C}$ ) using a self-propelled boom sprayer equipped with flat fan nozzles. The commercial product contained $680 \mathrm{~g} \mathrm{~L}^{-1}$ of the active ingredient triclopyr-butotylEC (emulsifiable concentrate), and $1.5 \mathrm{~L} \mathrm{ha}^{-1}$ of the commercial product was applied at a volume of $100 \mathrm{~L} \mathrm{ha}^{-1}$.

Triclopyr is a synthetic auxin indicated for the post-emergence control of weeds in irrigated rice and pastures and also for presowing in corn and soybeans (Sistema de Agrotóxicos Fitossanitário [AGROFIT], 2021). Due to the recent increase in the use of this product in areas that are being prepared for the cultivation of soybean, the associated injuries to vines have not yet been reported.

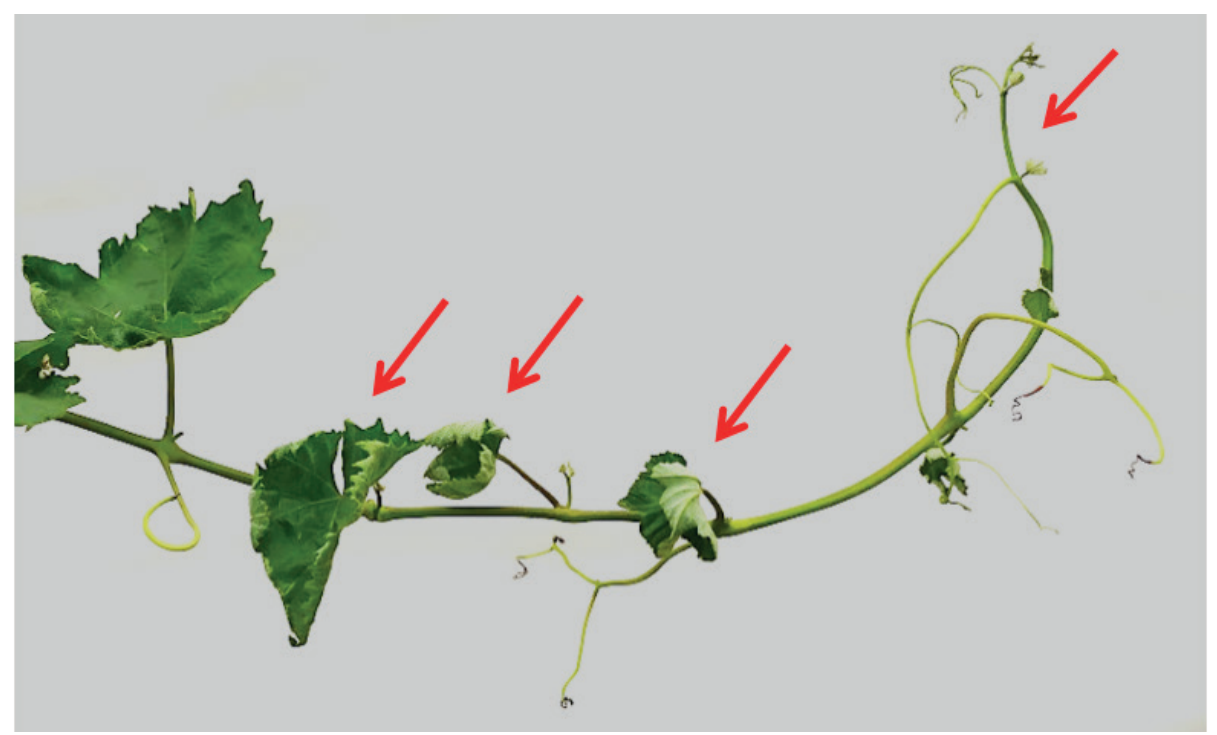

Figure 1. Initial injuries associated with triclopyr drift in emerging shoots of the 'Italia' table grape approximately 3 days after the drift. These injuries are characterized by the wilting of the shoot tip (arrow on right) and a shriveling of the youngest leaves (arrows on center). 

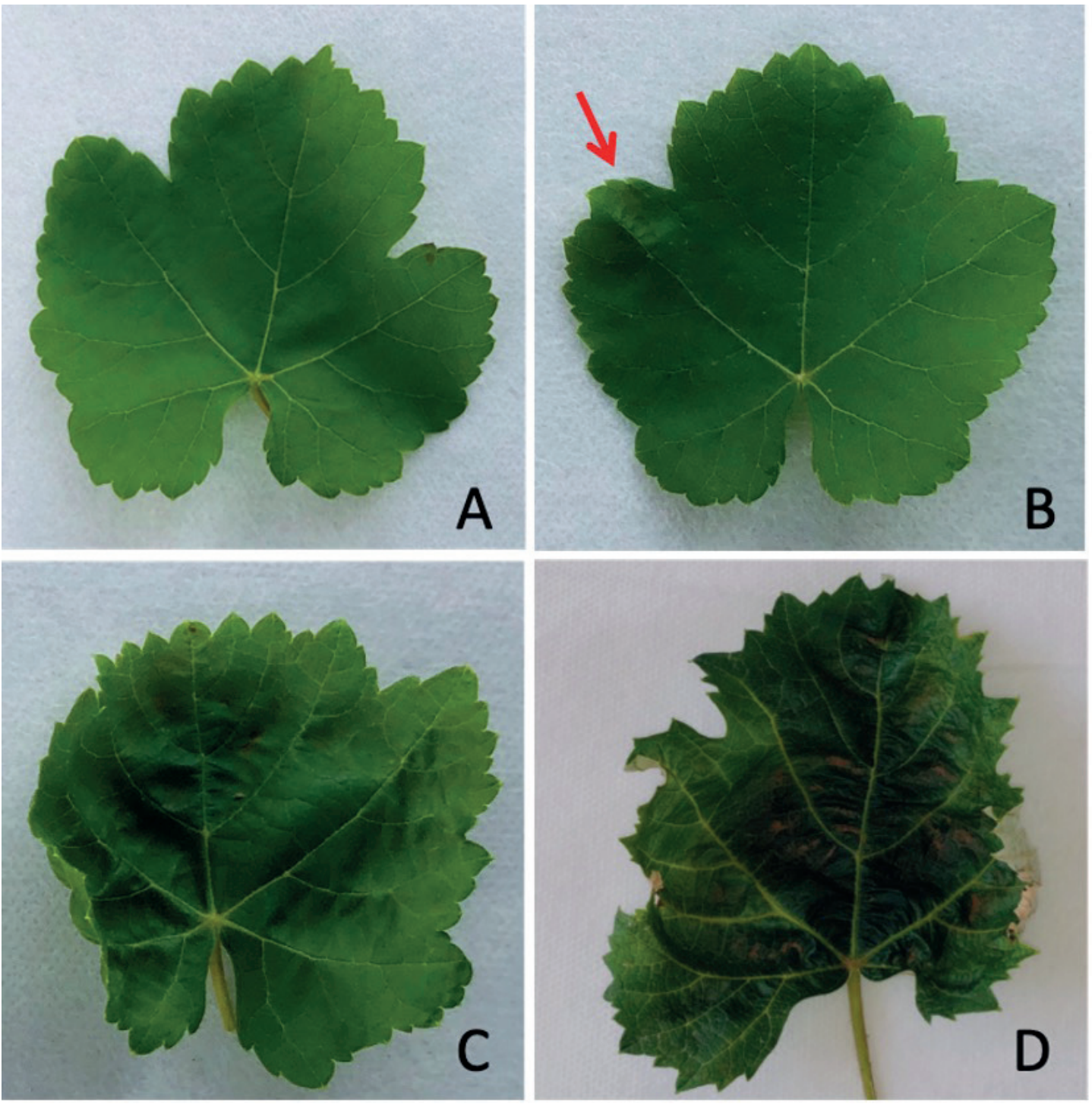

Figure 2. Injuries associated with triclopyr drift in the context of table grape leaves. A: intact leaf that was collected from vines not exposed to herbicide drift and without injuries; B: leaf with localized injury that is characterized by a shortening of the lobe (arrow); C and D: injured leaves exhibiting a generalized, shriveled, and leathery appearance.

When observing in table grapes any of the injuries associated with the drift of this herbicide, it must be taken into consideration that these injuries developed over time and not simultaneously. When the vines were between the pre-flowering and fruit set stages and in close proximity to the herbicide application area (approximately $50 \mathrm{~m}$ apart), the emergence of grape bunches did not occur, and the production was completely lost. When the vines were located further away from this application area (approximately 2,000 m apart), the grape flowers were aborted, and the tips of the grape bunches became dry and emerged as small and/or thin deformed bunches. 
In the vineyards that were in more advanced developmental stages when affected by the herbicide drift (even with the berries already emerged), the abortion and drop of berries of the tips was observed, and the growth of the remaining berries and shoots was also completely interrupted. In addition to shriveled leaves, the severely affected vineyards subsequently died of shoot tip dysfunction in combination with necrosis of the youngest leaves and apical meristems (Figure 3A). Another frequently observed symptom was the occurrence of eruptions in the form of galls on the shoot nodes that involved the lateral buds (Figure 3D).
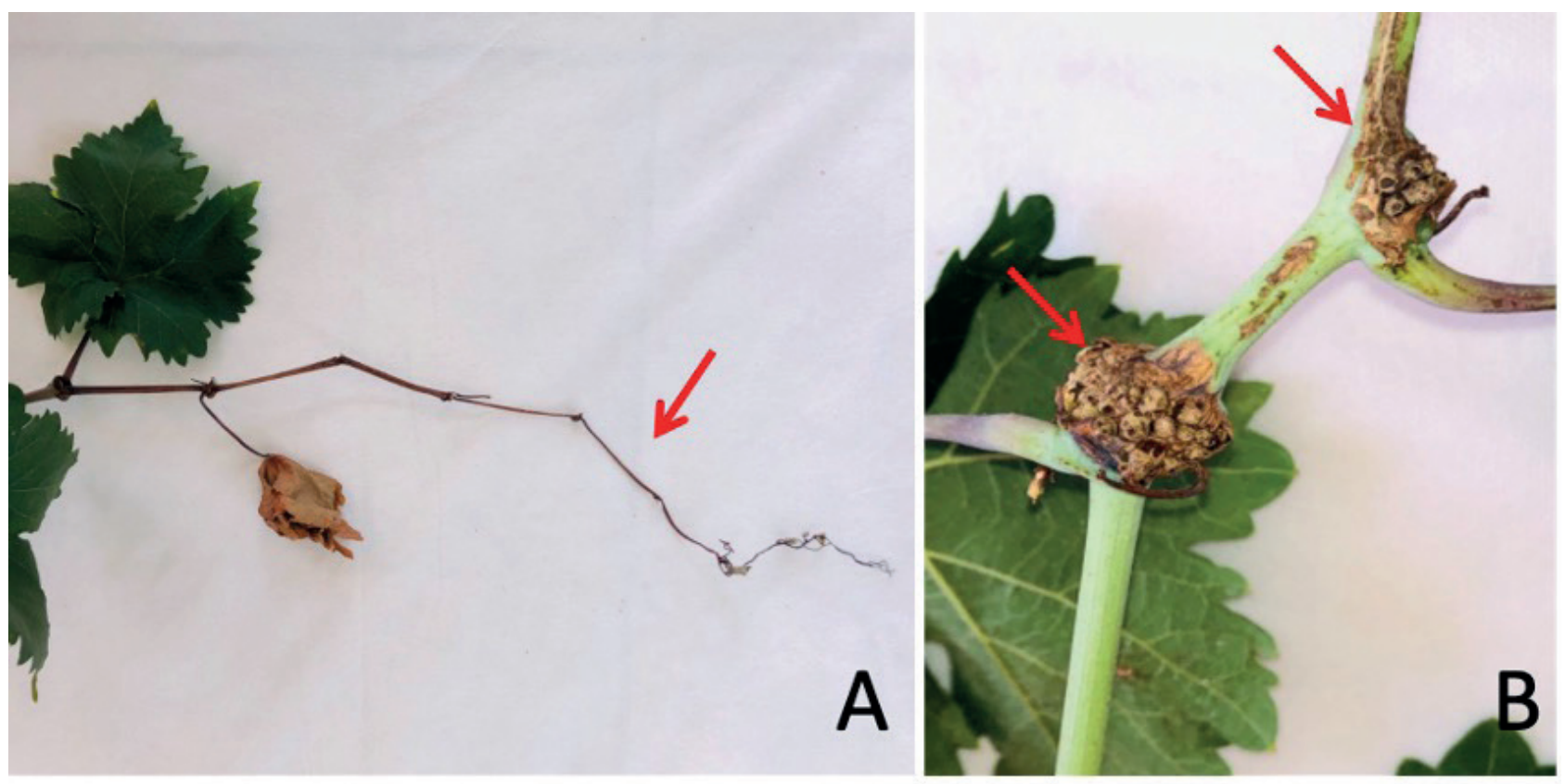

Figure 3. Injury associated with triclopyr drift in the context of a 'BRS Vitoria' table grape at approximately 30 days after the drift. A: death of the shoot tip with necrotic tissues (arrow); B: occurrence of eruptions in the form of galls in the shoot nodes and involving the lateral buds (arrows).

Due to the drift of triclopyr, in the majority of the affected vineyards an interruption or reduction in shoot growth was observed, and the shoot tipping practice was not necessary to control the growth of the vines. In the vineyards located further away from the herbicide application area, unlike what normally occurs with 2,4-D drift, no injuries were observed in leaves or shoots in addition to the observed growth interruption (Figure 4) that is a major problem for crop management, as it could be mistakenly attributed to factors other than triclopyr drift. 


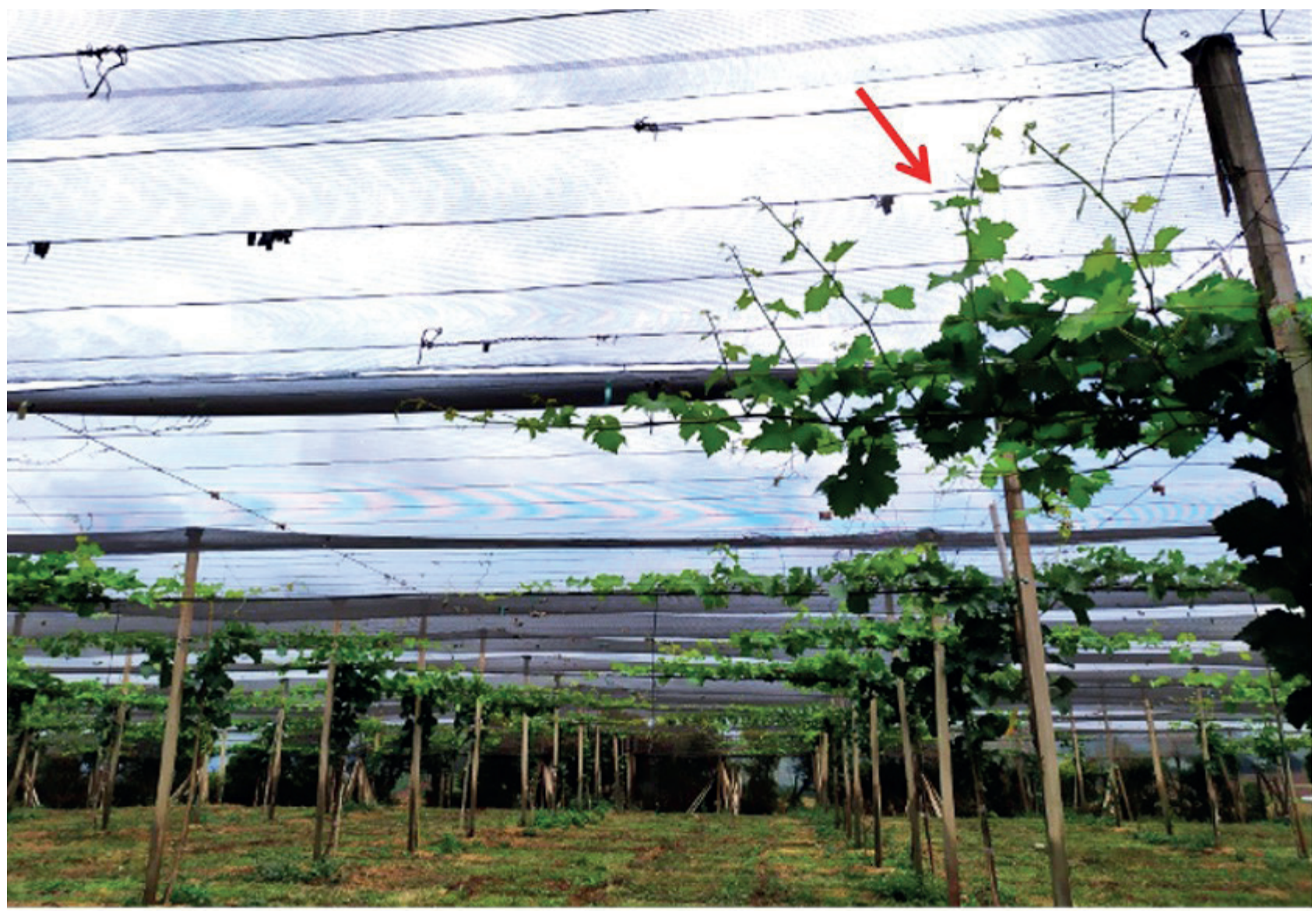

Figure 4. Injury associated with triclopyr drift in young vines at approximately 60 days after the drift. In the background, the vines were grafted at the end of winter (July) and experienced growth interruption that mainly influenced the lateral shoots (canes); however, these shoots underwent vigorous development prior to the drift. In contrast, the highlighted vine (arrow) possesses lateral shoots (canes) with good shoot development that emerged from a green-grafting process that was performed at approximately 30 days after the drift (October). Therefore, the rootstock shoots were the ones exposed to the herbicide drift at that time; however, they were removed immediately after the green-grafting was performed. As a result, the shoot growth from this grafting was not interrupted, and the vine exhibited good development.

Therefore, the most significant and easily observe injury occurred within the bunches, and this injury occurred regardless of the stage of development. The grape bunches from vines located in close proximity to the herbicide application area became totally or partially dry. Aborted berries were present primarily in the bunch tips (Figure
$5 \mathrm{~A})$, and cracks in the peduncle (Figure 5B) and deformed bunches (Figure $5 \mathrm{C}$ ) were also eventually observed.

When the herbicide drift occurred after vine flowering, the bunch tips of the 'BRS Nubia' and 'Brasil' grapes that possess black-colored berries when the full ripe stage is reached acquired a reddish color 


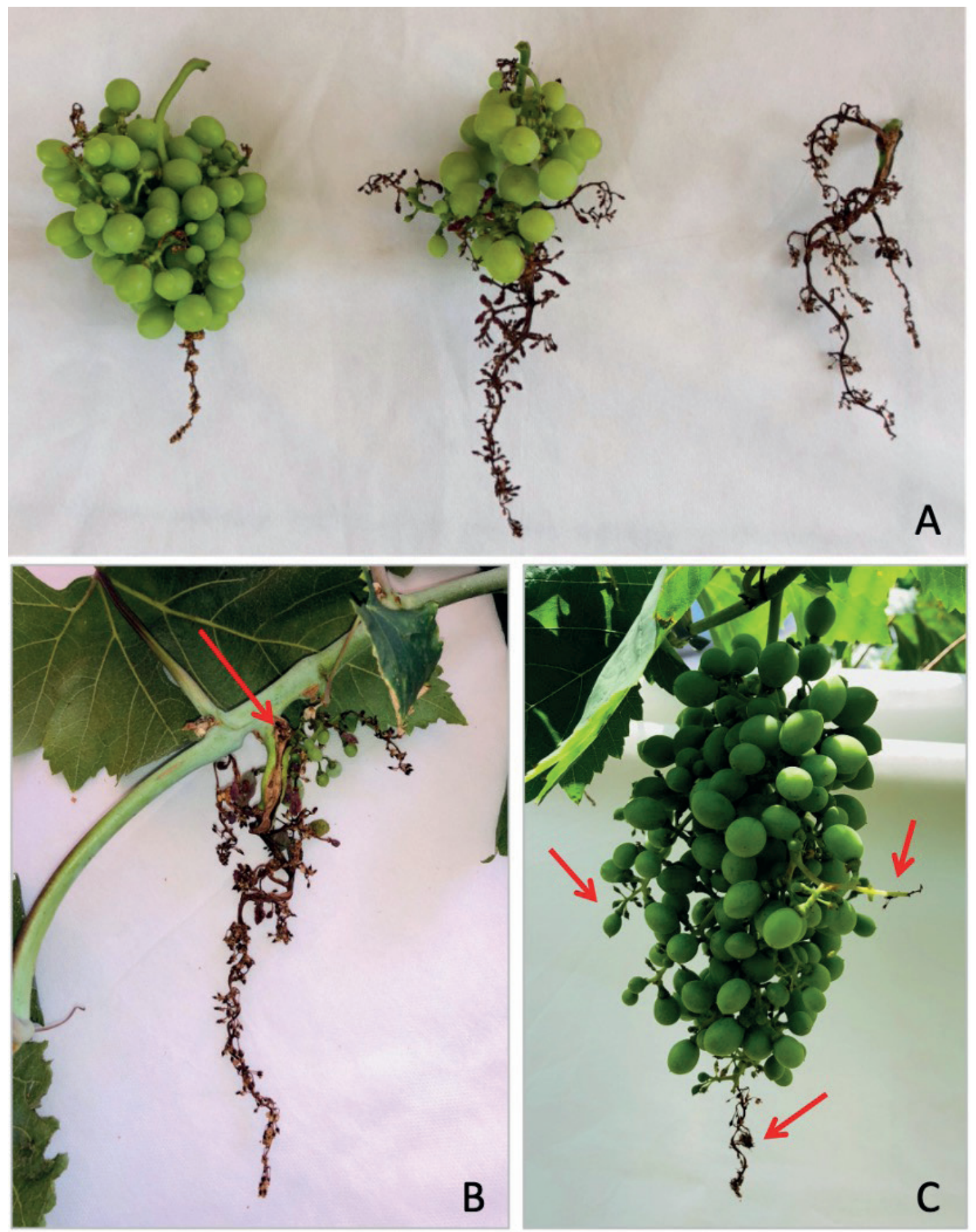

Figure 5. Injuries associated with triclopyr drift in bunches of table grapes. A: bunches of 'Italia' table grapes at the pea-size stage possessing different injury intensities that included moderate (left), severe (center), and intense (right) at approximately 40 days after the drift; B: bunches of 'Italia' table grapes that were totally injured and exhibited aborted berries and cracked rachis (arrow) at approximately 40 days after the drift; $\mathrm{C}$ : bunches of 'BRS Nubia' table grapes at the pea-size stage exhibiting tip drying (arrow on bottom) and some lateral berry clusters that were injured (arrows on left and right) at approximately 30 days after the drift. 

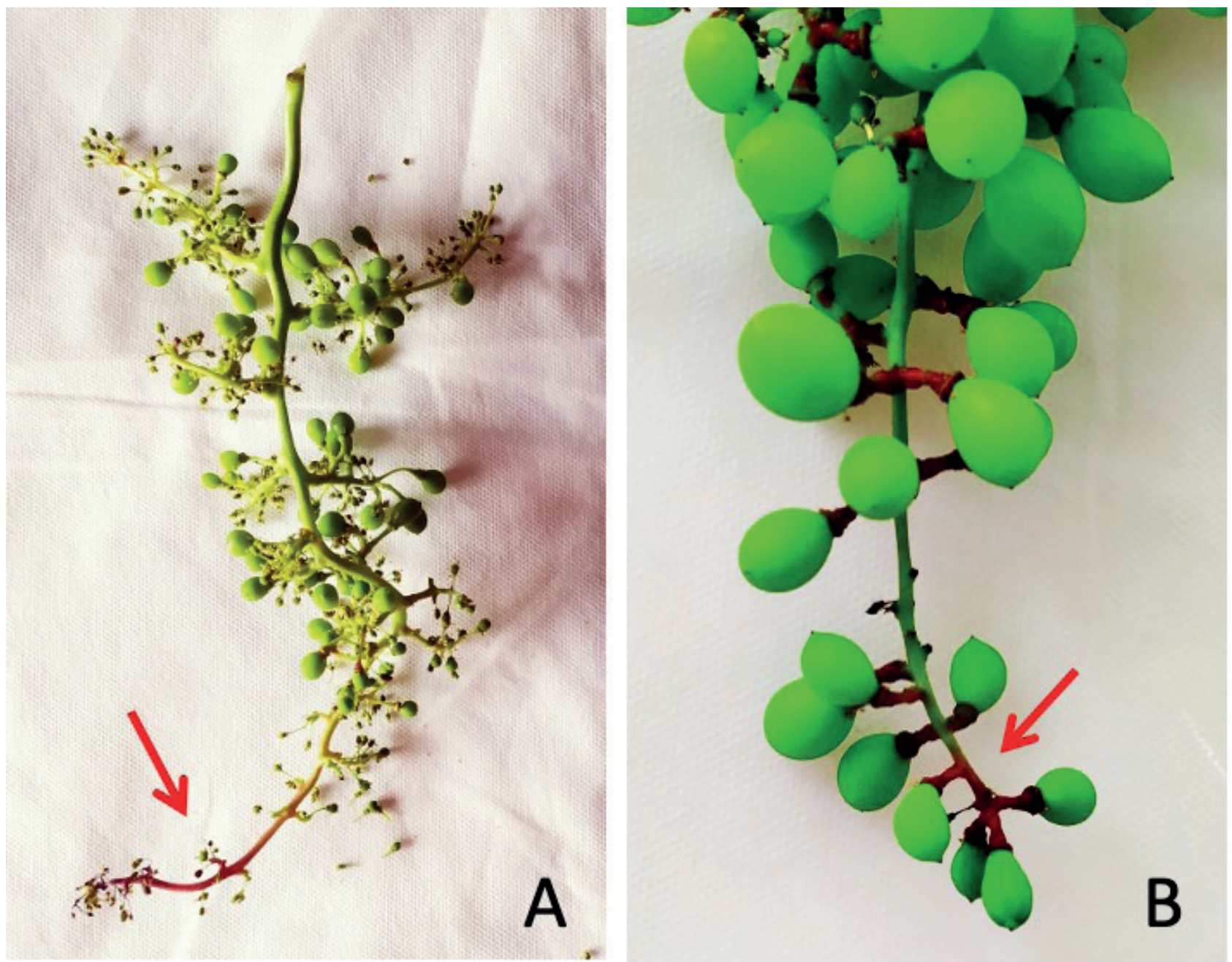

Figure 6. Injury associated with triclopyr drift after flowering on 'Brasil' table grapes at different stages of development. A and B: bunches at the peppercorn and at pea-size stages, respectively, exhibiting reddish tips (arrows).

(Figure 6). Reddening of the bunch tips has not been previously observed in these cultivars, and it can be considered a typical symptom associated with triclopyr drift. In the 'Italia' grape group, the most typical injury associated with the occurrence of triclopyr drift that occurred when the vines were at post-flowering stage was the thickening of the pedicels, particularly those located at the bunch tip that became highly lignified, fused, and brown in color (Figure 7). The vines that were closest to the herbicide application site exhibited the thickest berry pedicels. 

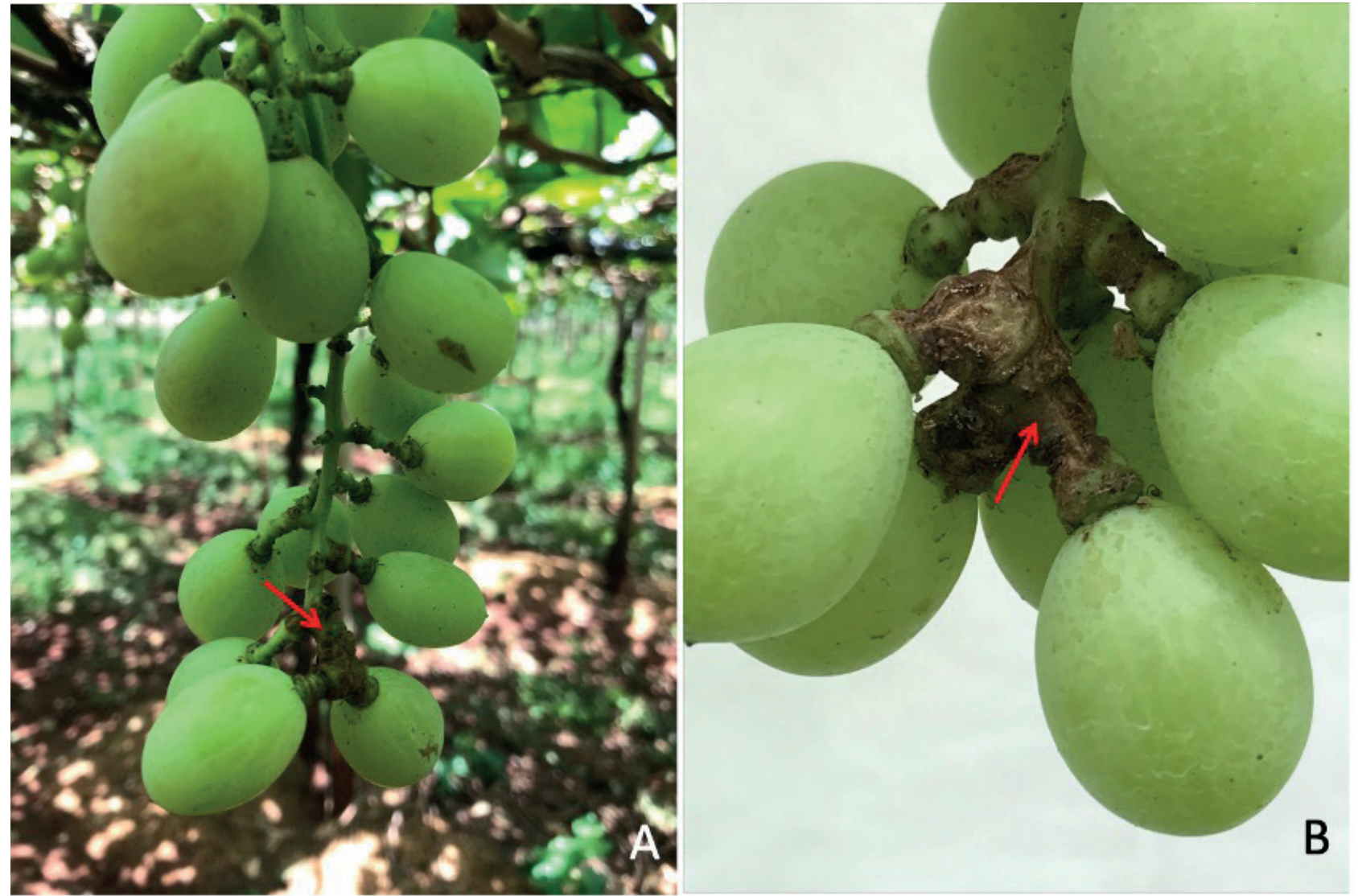

Figure 7. Injury associated with triclopyr drift at the post-flowering stage in 'Italia' table grape bunches. A and B: thickening of the pedicels at the tip of the bunch (arrows) at approximately 40 days after the drift.

Triclopyr possesses physicochemical characteristics (log kow: -1.5; pKa: 3.04) that allow it to move through the xylem; however, it moves primarily through the phloem (Shaner, 2014), and this explains the occurrence of the associated injuries in the growth portions of the vines such as the shoots, raquis, and bunch tips due to the more intense flow of photoassimilated compounds that carry the herbicide to the plant meristems. The thickening of the pedicels and the formation of galls may be related to the increased production and accumulation of gibberellins when the vines are exposed to auxins (Ross, O'Neill, Wolbang, Symons, \& Reid, 2002).
The associated injuries that were observed with greater intensity and severity occurred in the vineyards located closer to the soybean production area where the herbicide triclopyr was applied approximately 50 m away. However, mild to moderate damage was also observed in vines located up to 2,000 m away from the application site. Triclopyr possesses a vapor pressure of $5 \times 10^{-5} \mathrm{~Pa}$ at $25^{\circ} \mathrm{C}$, which classifies it as a low volatile herbicide with low potential for volatilization (Shaner, 2014). However, given the high sensitivity of vines to this type of herbicide, volatilization can contribute to the occurrence of mild injuries. 
Thus, preventive measures must be undertaken when triclopyr is applied. In particular, applications must be made at a distance of not less than 2,000 $\mathrm{m}$ from areas containing sensitive species such as vines, particularly when the wind direction favors drift. Additionally, applications should not be performed on days with wind speeds above $6 \mathrm{~km} \mathrm{~h}^{-1}$ when the temperature is above 30 ${ }^{\circ} \mathrm{C}$ or when the relative humidity is less than $60 \%$, and appropriate application technology should be considered using operating pressure and nozzles that produce large drops (above $200 \mu$ ) and spray volumes ranging from 150 to $200 \mathrm{~L} \mathrm{ha}^{-1}$ (AGROFIT, 2021). Mixing of auxinic herbicides with glyphosate should also be avoided in areas that are in close proximity to sensitive species, as this practice increases its drift potential (Oliveira, Gandolfo, Oliveira, Oliveira, \& Martins, 2019).

Grapevine is a stem-tendril climbing species that grows upwards with vigorous overhanging growth that requires training systems for the development of its structure, thus facilitating agricultural practices such as pruning, canopy management, mechanization, and harvesting. As they are temperate species, vines must be pruned every growing season at the same time that their vegetative structures such as canes and buds are renewed. The buds of the vines that originated from shoots with new buds lived for approximately one year. In each new growing season, the emerged shoots and buds define the yield of the next season. For this reason, the injuries associated with triclopyr drift in table grapes will exert a direct impact on the next growing season, regardless of the stage in which the vines are affected (young or mature vines).

According to the first report of injuries associated with triclopyr drift, the young vine nurseries whose grafting of the scion onto rootstocks was performed at the end of winter under field conditions experienced growth interruption when affected by the drift, and the vines, even those grated onto vigorous rootstocks such as 'IAC 766 Campinas', could not adequately form their cordons (arms) or the canes to support pruning during the next growing season. Thus, a delay in the emergence of the structure of the grapevines will result in losses during the first harvest season until the ideal number of canes is formed to obtain an optimal yield.

The mature vines that were severely affected when the bearing shoots were in development $(30-40 \mathrm{~cm}$ in length from base to tip) also experience growth interruption or shoot tip injury, and under these conditions, bunches did not emerge. At this developmental stage, the grapevines possessed insufficient nutrient reserves to establish new growth if necessary, and the growers decided not to repeat the pruning and to let the vines attempt to complete the cycle and metabolize the herbicide. Under these conditions, the shoots reached the mature stage, and the remaining leaves exhibited low storage reserve accumulation. Pruning was then performed in December and January (early summer) on canes that emerged under the triclopyr drift or on older canes (>1-year-old) when the development of the emerged canes was weak. The budburst was not highly vigorous due to the low storage reserve accumulation, and the shoot possessed a reduced number of bunches due to the low quality of the buds; however, there were no visible injuries associated with the herbicide.

The vines that were slightly affected by the triclopyr drift at different phenological stages exhibited impaired shoot development, 
where instead of shoots exhibiting the ideal length (1.60 m-long), they exhibited variable lengths that ranged from $0.70 \mathrm{~m}$ to $1.60 \mathrm{~m}$-long when the tipping to control shoot growth was performed. Pruning to obtain the off-season crop that should have been performed on these shoots when they reached their mature stage during the summer, with 12-14 buds retained per cane, was instead performed in a shorter manner with 6-8 buds retained per cane. Eventually, 10 buds were retained per cane. When the vines are pruned again at the end of the winter of 2021 to promote a new growing season, the canes will be pruned in an even shorter manner that will certainly reduce the number of bunches per vine and consequently the yield, as the buds located at the base of the canes of these grape cultivars tend to be less fruitful than are those located in the mid- or apical-cane portions. Similar to the severely affected vines, no bud injuries were observed in these new shoots that could cause deformation of the buds or the absence of bunches. In summary, in the severely affected areas the expected yield loss in the following harvest seasons is due to the difficulty in forming shoots that support the double cropping-a-year system. This effect is caused by triclopyr drift due to interrupting of the shoot growth development and not from a difficulty of the shoots in forming fruitful buds in the following growing seasons.

From a general point of view, the application of herbicides in soybean areas in close proximity to the cultivation of table grapes and also to other sensitive species presents a very large risk that can negatively impact the development of these crops, ultimately causing losses that can last for several growing seasons. Thus, strictly following the instructions contained in the herbicide label instructions while also consulting a trained professional are fundamental measures that can be undertaken to prevent situations like this from occurring or can at least mitigate them. Finally, this is the first report detailing injuries associated with triclopyr herbicide drift in grapevines; however, controlled trials to characterize the damage levels and other implications are required to better understand the herbicide drift effect at different developmental stages of grapevines.

\section{References}

Ahmed, S., Roberto, S. R., Shahab, M., Colombo, R. C., Silvestre, J. P., Koyama, R., \& Souza, R.T. de. (2019). Proposal of double-cropping system for 'BRS Isis' seedless grape grown in subtropical area. Scientia Horticulturae, 251, 118-126. doi: 10.1016/j.scienta.2019.03.022

Cobb, A. H., \& Reade, J. P. H. (2010). Herbicides and plant physiology (7nd ed.). Hoboken: Wiley Publishers.

Felsot, A.S., Unsworth, J. B., Linders, J. B., Roberts, G., Rautman, D., Harris, C., \& Carazo, E. (2011). Agrochemical spray drift; assessment and mitigation a review. (2010). Journal of Environmental Science Health, Part B, 46(1), 1-23. doi: 10.1080/03601234.2010.515161

Genta, W., Tessmann, D. J., Roberto, S. R., Vida, J. B., Colombo, L. A., Scapin, C. R., Clovis, L. R. (2010). Manejo de míldio no cultivo protegido de videira de mesa 'BRS Clara'. Pesquisa Agropecuária Brasileira, 45(12), 1388-1395. doi: 10.1590/S0100204X2010001200008 
Hansen, H., \& Grossmann, K. (2000). Auxininduced ethylene triggers abscisic acid biosynthesis and growth inhibition. Plant Physiology, 124(3), 1437-1448. doi: 10. 1104/pp.124.3.1437

Heap, I. (2020). The international herbicideresistant weed database. Corvalis: WeedScience. Retrieved from http://www. weedscience.org/Home.aspx

Instituto Brasileiro de Geografia e Estatística (2019). Tabela 1618: área plantada, área colhida e produção, por ano da safra e produto das lavouras. Rio de Janeiro: IBGE. Recuperado de https://sidra.ibge. gov.br/tabela/1618

Kishino, A. Y., Marur, C. J., \& Roberto, S. R. (2019a). Características da planta. Variedades-copa e Porta-enxertos. In A.Y. Kishino, S. L. C. de Carvalho, \& S. R. Roberto, Viticultura tropical: o sistema de produção de uvas de mesa do Paraná (pp. 201-249). Londrina: IAPAR.

Kishino, A. Y., Roberto, S. R., \& Genta, W. (2019b). Implantação do pomar. In A. Y. Kishino, S. L. C. de Carvalho, \& S. R. Roberto (Eds.), Viticultura tropical: o sistema de produção de uvas de mesa do Paraná (pp. 251-301). Londrina: IAPAR.

Nascimento, E. R., \& Yamashita, O. M. (2009). Desenvolvimento inicial de olerícolas cultivadas em solos contaminados com resíduos de 2,4-D + picloram. Semina: Ciências Agrárias, 30(1), 47-54. doi: 10. 5433/1679-0359
Oliveira, G. M. P., Gandolfo, M. A., Oliveira, R. B., Oliveira, S. M. P., \& Martins, V. A. (2019). Potential drift and injury of herbicides sprayed in a wind tunnel. Engenharia Agrícola, 39(1), 75-82. doi: 10.1590/18094430-eng.agric.v39n1p75-82/2019

Oliveira, R. S., Jr., Constantin, J., Brandão, J. U.T., Fo., Callegari, O., Pagliari, P. H., Cavalieri, S. D.,... Roso, A. C. (2007). Efeito de subdoses de 2,4-D na produtividade de uva Itália e suscetibilidade da cultura em função de seu estádio de desenvolvimento. Engenharia Agrícola, 27(Spe), 35-40. doi: 10.1590/S0100-69162007000200006

Ross, J. J., O'Neill, D. P., Wolbang, C. M., Symons, G. M., \& Reid, J. B. (2002). Auxin-gibberellin interactions and their role in plant growth. Journal of Plant Growth Regulation, 20(4), 346-353. doi: 10.1007/s003440010034

Shaner, D. L. (2014). Herbicide handbook (10nd ed.). Champaign, IL: Weed Science Society of America.

Sistema de Agrotóxicos Fitossanitário (2021). Consulta de ingrediente ativo. Brasília: MAPA. Retrieved from http://agrofit. agricultura.gov.br/agrofit_cons/principal_ agrofit_cons

Tahmasebi, B. K., Alebrahim, M. T., RoldánGómez, R. A., Silveira, H. M., Carvalho, L. B., Alcántara-de La Cruz, R., \& Prado, R. (2018). Effectiveness of alternative herbicides on three Conyza species from Europe with and without glyphosate resistance. Crop Protection, 112, 350-355. doi: 10.1016/j. cropro.2018.06.021 
